\title{
PENGARUH PENGGUNAAN PUPUK MAJEMUK (NPK) TERHADAP PRODUKSI KEDELAI
}

\section{THE INFLUENCE OF THE USE OF NPK FERTILIZER ON THE SOY PRODUCTION CAPABILITY IN FIELD LABORATORY}

\author{
SUPEKI $^{1}$ \\ IYoung Expert Lecturer at Agricultural Training Center Food Crop and \\ Horticulture Office, Papua Province, Indonesia e-mail: imam.supeki01 @ gmail.com
}

\begin{abstract}
Abstrak
Dalam budidaya kedelai penggunaan pupuk diperlukan baik dalam bentuk tunggal ataupun majemuk. Mengingat harga pupuk cukup mahal, penggunaannya harus efisien. Permasalahan yang dihadapi dimana masih sering dijumpai petani tidak memupuk tanaman kedelainya. Padahal tanaman kedelai memerlukan hara N, P, dan K yang tinggi. Penelitian ini dilaksanakan di kebun percobaan Balai Latihan Pertanian Dinas Tanaman Pangan dan Hortikultura Provinsi Papua pada bulan Mei s/d bulan Agustus 2016. Adapun analisa datanya dilakukan dengan menggunakan tabulasi dan diolah menggunakan program Excel. Penanaman kedelai varietas Anjasmoro dilakukan dengan penggunaan pupuk majemuk NPK padat 15-15-15+TE merek DGW produksi dari PT. Hextar Fertilizer Indonesia dengan dosis $140,06 \mathrm{~kg} / \mathrm{ha}$ dapat menghasilkan rata-rata tinggi tanaman $86,85 \mathrm{~cm}$ dan hasil panen dengan produksi 3,83 ton/ha serta bobot 100 biji adalah 17 gr/100 biji. Kenyataan tersebut menunjukkan bahwa penggunaan pupuk majemuk NPK dapat direkomendasikan pemakaiannya sebagai pupuk susulan untuk meningkatkan pertumbuhan dan produksi kedelai. Walaupun demikian, pupuk majemuk NPK juga bisa digunakan sebagai pupuk dasar bila ketersediaan pupuk tunggal N,P, dan $\mathrm{K}$ tidak tersedia atau lebih mahal dengan memperhatikan kecukupan atau dosis pemakaiannya.
\end{abstract}

\section{Kata kunci : pupuk NPK, produksi, kedelai.}

\begin{abstract}
In soybean cultivation the use of fertilizers is needed in both single and compound forms. Given that fertilizer prices are quite expensive; their use must be efficient. Problems faced where farmers are still often not cultivating soybean plants. Though soybean plants require high $\mathrm{N}, \mathrm{P}$, and $\mathrm{K}$ nutrients. The research was carried out in the experimental gardens of the Agricultural Training Center for the Food and Horticulture Crops of Papua Province in May to August 2016. The data analysis was done using tabulation and processed using the program Excel. Planting Anjasmoro variety of soybeans was done using NPK compaction 15-15-15 + TE compound DGW production from PT. Hextar Fertilizer Indonesia with a dose of $140.06 \mathrm{~kg} /$ ha can produce an average plant height of $86.85 \mathrm{~cm}$ and yields with a production of 3.83 tons / ha and a weight of 100 seeds is $17 \mathrm{gr} / 100$ seeds. This fact shows that the use of NPK compound fertilizer can be recommended as a supplementary fertilizer to increase soybean growth and proudness. However, NPK compound fertilizer can also be used as a basic fertilizer if the availability of a single fertilizer $\mathrm{N}, \mathrm{P}$, and $\mathrm{K}$ is not available or more expensive with regard to the adequacy or dosage of its use.
\end{abstract}

Keywords : NPK fertilizer, production, soybeans. 


\section{PENDAHULUAN}

Program pemerintahan Presiden Jokowi di bidang pertanian terfocus pada pencapaian swasembada pangan dalam hal ini adalah Padi, Jagung dan Kedelai (Pajale). Tidak tanggung-tanggung pemerintah menargetkan swa sembada pangan bagi bangsa Indonesia tersebut harus tercapai dalam waktu tiga tahun (Tahun 2018). Keseriusan pemerintah dalam hal ini adalah penyediaan dana yang cukup besar dalam upaya pencapaian target tersebut.

Saat ini upaya untuk meningkatkan produksi kedelai yang paling memungkinkan adalah dengan cara meningkatkan produktivitas dan menambah luasan areal pertanaman kedelai. Data statistik menurut Badan Pusat Statistik (2012) menunjukkan bahwa dalam kurun waktu lima belas tahun terakhir, rata-rata produktivitas kedelai nasional tidak mengalami perkembangan berarti dan stagnan di kisaran 1,1 - 1,3 t/ha. Sementara itu, hasil penelitian menunjukkan bahwa melalui program PTT produksi kedelai di tingkat petani bisa mencapai 1,7 - 3,2 t/ha. Beberapa varitas kedelai yang telah dilepas, produktivitasnya bisa mencapai lebih dari 3 t/ha. Senjang produktivitas yang cukup lebar ini merupakan indikasi penerapan teknologi budidaya kedelai oleh petani belum berada pada rel yang benar. Dengan demikian, produksi kedelai nasional sejak tahun 1992 terus merosot dan lebih banyak ditentukan oleh luas areal panen.

Upaya meningkatkan produksi kedelai nasional dapat ditempuh dengan tiga pendekatan yaitu 1) peningkatan produktivitas, 2) peningkatan intensitas tanam dan 3) perluasan areal tanam. Upaya peningkatan produktivitas dapat ditempuh melalui perbaikan varietas, perbaikan teknik budidaya dan menekan kehilangan hasil melalui perbaikan sistem panen dan pasca panen.Peningkatan intensitas tanam dengan menanam kedelai berturut-turut ditengarai kurang baik karena ada efek alelopati terhadap tanaman kedelai yang kedua.

Upaya peningkatan produktivitas dapat dilakukan dengan perbaikan kondisi lahan dengan ameliorasi, pemupukan berimbang dan terpadu, penggunaan varietas unggul dan perbaikan tata air. Alternatif teknologi ameliorasi dan pemupukan telah tersedia namun perlu disesuaikan dengan kondisi lahan setempat mengingat adanya variasi potensi kesesuaian lahannya. 
Dalam budidaya kedelai penggunaan pupuk diperlukan baik dalam bentuk tunggal ataupun majemuk. Mengingat harga pupuk cukup mahal, penggunaannya harus efisien. Penelitian yang dilakukan Ernawanto, dkk. (2011), peneliti pada Balai Pengkajian Teknologi Pertanian Jawa Timur, dan pengajar Politeknik Negeri Jember menunjukkan, aplikasi pupuk memberi hasil positif pada tanaman kedelai, bukan hanya produksi yang meningkat tetapi juga kualitas biji kedelai. Hasil pengkajian yang dilakukan di desa Gambirono, kecamatan Bangsalsari, Jember menunjukkan bahwa penggunaan pupuk PHONSKA sebanyak $75 \mathrm{~kg} / \mathrm{ha}$ memberi hasil panen kedelai sebanyak 2,33 t/ha atau hasil meningkat 24\% dibanding tanpa PHONSKA.

\section{METODE PENELITIAN}

Penelitian ini dilaksanakan di kebun percobaan Balai Latihan Pertanian Dinas Tanaman Pangan dan Hortikultura Provinsi Papua yang terletak di Jalan Yahim, Kelurahan Dobonsolo Distrik Sentani, Kabupaten Jayapura pada bulan Mei s/d bulan Agustus 2016.

\section{Prosedur Penelitian}

\section{Penyiapan Lahan}

Lahan yang digunakan untuk tempatpercobaan adalah lahan bekas alangalang. Selanjutnya untuk pembersihan gulma pada lahantersebut dilakukan dengan cara mencabut gulma lalu melakukan pengolahan tanah secukupnya. Selanjutnya dilakukan penyemprotan herbisida (Supremo 480 SL) sebelum dilakukan penanaman untuk membunuh dan mencegah tumbuhnya gulma sebelum penanaman.

\section{Penanaman dan Pemeliharaan}

Penanaman dilakukan setelah pengolahan lahan dan pembersihan lahan dari gulma dengan menggunakan herbisida. Penanaman dilakukan setelah \pm 1 minggu setelah penyemprotan.Benih Kedelai yang digunakan adalah varietas Anjasmoro yang ditanam dengan jarak tanam 40 × 20 dengan menggunakan tali dan tugal dengan kedalaman $\pm 3 \mathrm{~cm}$, dimana setiap lubang tanam diisi 2 biji.Sebelum dilakukan penanaman, dilakukan perlakuan benih dimana benih kedelai dicampur dengan marsha 25 ST ditambah dengan regent untuk menghindari atau sebagai pengendalian dari serangga. Lubang tanam ditutup dengan menggunakan tanah bekas penanaman kacang tanah disertai pemupukan dasar dimana pupuk dasar 
yang digunakan adalah TSP 36 dan Pupuk Urea dengan dosis urea $50 \mathrm{~kg} / \mathrm{ha}$ $(0,18 \mathrm{~kg} /$ petak) dan TSP 36 150kg/ha $(0,54 \mathrm{~kg} /$ petak $)$.

Pemeliharaan meliputi penyiangan, penyiraman dan pemupukan susulan. Penyiangan dilakukan minimal 2 kali atau melihat kondisi gulma, sedangkan penyiraman dilakukan sesering mungkin terutama saat pertumbuhan awal, fase berbunga dan fase pengisian polong. Pemupukan susulan dilakukan hanya sekali (8 HST) dengan menggunakan pupuk majemuk NPK compaction 15-1515+TE merek DGW produksi dari PT. Hextar Fertilizer Indonesia dengan dosis 500gr per luas petak tanam $(35,7 \mathrm{~m} 2)$ atau 140,06 kg/ha. Adapun cara pemupukan dilakukan dengan membuat lubang ajir diantara tanaman lalu ditabur pupuk, kemudian dtutup kembali.

\section{Pemanenan dan Pasca Panen}

Pemanenan kedelai dilakukan pada umur 90 HST dimana 95\% polong pada batang utama telah berwarna kuning kecoklatan, dengan ciri-ciri tanaman mengering, berwarna kuning, batang mulai mengeras, polong keras dan berubah warna menjadi kecoklatan. Pemanendilakukan dengan cara memotong pangkal tanaman menggunakan parang.
Hasil panen yang dikumpulkan per tanaman/lubang tanaman tanaman masingmasing kedalam kantong plastik agar sampel tidak tertukar datanya nanti. Selanjutnya brangkasan tanaman dijemur dengan terlebih dahulu diberi tanda agar tidak tertukar datanya sampai brangkasan kering, dimana bila polong ditekan dan bijinya keluar dengan mudah (KA 15-16 $\%$ ) maka pengeringan brangkasan dicukupkan.

\section{4. pengambilan data hasil panen.}

Pengumpulan data yang dilakukan adalah panjang/tinggi tanaman dan laju tinggi tanaman serta dan hasil panen dari tanaman.

\section{Panjang/Tinggi dan laju tinggi} tanaman, pengukur tinggi tanaman dilakukan dari leher akar (permukaan tanah) sampai titik tumbuh (tunas) terakhir pada batang utama. Pengukuran dilakukan setelah tanaman berumur 16 HST dan 30 HST.

Pengukuran laju tinggi tanaman dengan menggunakan rumus :

Laju tinggi tanaman $=\frac{\text { pertambahan tinggi }(\mathrm{cm})}{\text { selang waktu (hari) }}$ 
2. Hasil Panen, panen dilakukan apabila 95\% polong pada batang utama telah berwarna kuning kecoklatan. Pada penelitan Anjosmoro dilakukan pada umur 90 HST, dengan ciri-ciri tanaman mengering, ber-warna kuning, batang mulai mengeras, polong keras dan berubah warna menjadi kecoklatan dengan cara memotong pangkal tanaman menggunakan sabit. Panen dilakukan pada waktu sore hari dari pukul 15.00 sampai selesai. Hasil dari panenan ini segera dijemur selama beberapa hari setelah dirasa cukup (kalau digebuk bijinya sudah mudah terkelupas dari polongnya.

Jumlah Polong, Jumlah polong bernas per tanaman (buah) dilakukan dengan cara menghitung satu persatu polong bernasyang ada pada setiap tanaman sampel setelah terlebih dahulu dikeringkan;

Jumlah biji, jumlah biji per tanaman (buah)dihitung setelah polong tanaman peroleh dan polong dikupas untuk dikeluarkan bijinya;

Berat biji per tanaman (g), diperoleh dari semua biji kedelai setiap tanaman sampel yang ditimbang.

\section{HASILDAN PEMBAHASAN}

\section{Tinggi Tanaman dan Laju Tinggi \\ Tanaman}

Data tinggi tanaman kedelai diukur pada saat tanaman berumur 16 HST (Hari Setelah Tanam) dan 30/34 HST dengan cara mengukur mulai dari leher akar (permukaan tanah) sampai titik tumbuh (tunas) terakhir pada batang utama dari tanaman. Sedangkan untuk laju tinggi tanaman dihitung dengan cara membandingkan/membagi tinggi tanaman pada saat pengukuran dengan interval/selang waktu saat pengukuran.

Adapun hasil penelitian yang didapat dapat dilhat pada tabel di bawah ini :

Tabel 1 : Hasil Pengamatan Tinggi Tanaman dan Laju Tinggi Tanaman

\begin{tabular}{|c|c|c|c|c|c|c|}
\hline \multirow{2}{*}{$\begin{array}{c}\text { NO. } \\
\text { SAMPEL }\end{array}$} & \multicolumn{3}{|c|}{ TINGGI TANAMAN $(\mathrm{cm})$} & \multicolumn{3}{|c|}{ LAJU TINGGI TANAMAN } \\
\hline & 16 HST & $30 \& 34$ & 90 HST & 16 HST & $30 \& 34$ HST & 90 HST \\
\hline 1 & 9,7 & 34,5 & 88 & 0,61 & 1,77 & 0,89 \\
\hline 2 & 10,8 & 39,5 & 96 & 0,68 & 2,05 & 0,94 \\
\hline 3 & 11,2 & 42,5 & 87 & 0,70 & 2,24 & 0,74 \\
\hline 4 & 12,5 & 34 & 84 & 0,78 & 1,54 & 0,83 \\
\hline 5 & 12,5 & 40,5 & 84 & 0,78 & 2,00 & 0,73 \\
\hline 6 & 13 & 49 & 89 & 0,81 & 2,57 & 0,67 \\
\hline 7 & 10,5 & 37 & 88 & 0,66 & 1,89 & 0,85 \\
\hline 8 & 14 & 35 & 91 & 0,88 & 1,50 & 0,93 \\
\hline 9 & 12,5 & 41 & 96 & 0,78 & 2,04 & 0,92 \\
\hline 10 & 12,2 & 37 & 91 & 0,76 & 1,77 & 0,90 \\
\hline 11 & 12,5 & 45,5 & 90 & 0,78 & 2,36 & 0,74 \\
\hline 12 & 13,2 & 51,5 & 88 & 0,83 & 2,74 & 0,61 \\
\hline 13 & 12,2 & 37 & 79 & 0,76 & 1,77 & 0,70 \\
\hline 14 & 12,5 & 39,5 & 82 & 0,78 & 1,93 & 0,71 \\
\hline 15 & 13,5 & 41 & 77 & 0,84 & 1,96 & 0,60 \\
\hline 16 & 11,2 & 38 & 83 & 0,70 & 1,91 & 0,75 \\
\hline 17 & 13 & 44,5 & 88 & 0,81 & 2,25 & 0,73 \\
\hline 18 & 14 & 45,5 & 89 & 0,88 & 2,25 & 0,73 \\
\hline 19 & 12 & 35 & 85 & 0,75 & 1,64 & 0,83 \\
\hline 20 & 11,4 & 37 & 87 & 0,71 & 1,83 & 0,83 \\
\hline 21 & 11,3 & 35 & 90 & 0,71 & 1,69 & 0,92 \\
\hline 22 & 11,7 & 40,5 & 91 & 0,73 & 2,06 & 0,84 \\
\hline 23 & 12,6 & 37,5 & 92 & 0,79 & 1,78 & 0,91 \\
\hline 24 & 13,5 & 44 & 87 & 0,84 & 2,18 & 0,72 \\
\hline 25 & 11 & 39,5 & 86 & 0,69 & 2,04 & 0,78 \\
\hline
\end{tabular}




\begin{tabular}{|c|c|c|r|r|r|r|}
$-\cdot$ &,--- &.- &,-- &,--- \\
25 & 11 & 39,5 & 86 & 0,69 & 2,04 & 0,78 \\
26 & 11,4 & 33,5 & 89 & 0,71 & 1,58 & 0,93 \\
27 & 12,5 & 45 & 79 & 0,78 & 2,32 & 0,57 \\
28 & 13 & 45 & 92 & 0,81 & 2,29 & 0,78 \\
29 & 13,8 & 44 & 87 & 0,86 & 2,16 & 0,72 \\
30 & 14,6 & 40 & 89 & 0,91 & 1,81 & 0,82 \\
31 & 13 & 49 & 74 & 0,81 & 2,00 & 0,45 \\
32 & 11,5 & 46 & 99 & 0,72 & 1,92 & 0,95 \\
33 & 13,1 & 55 & 83 & 0,82 & 2,33 & 0,50 \\
34 & 11,5 & 50,5 & 68 & 0,72 & 2,17 & 0,31 \\
35 & 14,5 & 69,5 & 86 & 0,91 & 3,06 & 0,29 \\
36 & 12,5 & 57,5 & 91 & 0,78 & 2,50 & 0,60 \\
37 & 11,7 & 50 & 81 & 0,73 & 2,13 & 0,55 \\
38 & 13,1 & 56,2 & 100 & 0,82 & 2,39 & 0,78 \\
39 & 13,3 & 52 & 83 & 0,83 & 2,15 & 0,55 \\
40 & 12,5 & 44 & 92 & 0,78 & 1,75 & 0,86 \\
41 & 13,4 & 51,5 & 78 & 0,84 & 2,12 & 0,47 \\
42 & 11,4 & 46,5 & 84 & 0,71 & 1,95 & 0,67 \\
43 & 13,2 & 51,5 & 82 & 0,83 & 2,13 & 0,54 \\
44 & 13 & 54 & 85 & 0,81 & 2,28 & 0,55 \\
45 & 13 & 47,5 & 88 & 0,81 & 1,92 & 0,72 \\
46 & 14 & 52 & 92 & 0,88 & 2,11 & 0,71 \\
47 & 12,7 & 60,5 & 92 & 0,79 & 2,66 & 0,56 \\
48 & 12 & 40,5 & 87 & 0,75 & 1,58 & 0,83 \\
\hline JUMLAH & 599,2 & 2142,2 & 4.169 & 37,45 & 99,03 & 34,51 \\
\hline RATA-RATA & 12,48 & 44,63 & 86,85 & 0,78 & 2,06 & 0,72 \\
\hline & & & & & & \\
\hline
\end{tabular}

Sumber : Hasil Penelitian.

Pada tebel diatas dapat dilihat bahwa pada

16 HST rata-rata tinggi tanaman adalah $12,48 \mathrm{~cm}$ dimana yang paling pendek adalah $9,7 \mathrm{~cm}$ dan yang tertinggi adalah $14,6 \mathrm{~cm}$. Sedangkan untuk umur 30/34 HST rata-rata tinggi tanaman adalah 22,42 $\mathrm{cm}$ dimana yang paling pendek $33,5 \mathrm{~cm}$ dan yang paling adalah $69,5 \mathrm{~cm}$. Pada akhir pertumbuhan atau pada saat panen 90 HST rata-rata tinggi tanaman kedelai varietas Anjasmoro adalah 86,85 cm dimana yang terendah $68 \mathrm{~cm}$ dan yang tertinggi $100 \mathrm{~cm}$.

Rata-rata tinggi tanaman $68 \mathrm{~cm}$ (akhir pertumbuhan) menunjukkan bahwa dalam penelitian ini tinggi tanaman melampaui tinggi tanaman menurut deskripsi tanaman kedelai varietas Anjasmoro.Ini dapat terjadi karena dengan adanya penambahan pupuk majemuk NPK pada pemupukan susulan menjadikan tanaman dapat tumbuh dengan optimum yang disebabkan oleh adanya unsur hara yang ada dalam tanah tersedia secara optimal. Kenyataan ini sering/tidak jarang ditemukan oleh peneliti dimana hasil yang didapat melampui dari apa yang tercantum dalam deskripsi varietas tersebut. Salah satu contoh misalnya, percobaan yang dilakukan didapat hasil rata-rata tinggi tanaman kedelai varietas wilis adalah $59.37 \mathrm{~cm}$ telah melampaui tinggi tanaman menurut deskripsi yaitu $50 \mathrm{~cm}$.

Hasil data perhitungan untuk laju tinggi tanaman pada tabel di atas dapat dilihat rata-rata laju tinggi tanaman yang diambil pada $16 \mathrm{HST}$ adalah $0,78 \mathrm{~cm} /$ hari dimana yang tertinggi laju tinggi tanamannya adalah $0,91 \mathrm{~cm} /$ hari dan yang terendah laju tinggi tanamannya adalah $0,61 \mathrm{~cm} / \mathrm{hari}$. Untuk laju tinggi tanaman yang datanya diambil pada 30/34 HST rata-rata laju tinggi tanamannya adalah 2,06 dimana yang tertinggi laju tingginya adalah $3,06 \mathrm{~cm} /$ hari dan yang terendah adalah $1,50 \mathrm{~cm} /$ hari. Sedangkan laju tinggi tanaman sampai pada 90 HST rata-rata laju tinggi tanamannya adalah $0,72 \mathrm{~cm} /$ hari 
dimana yang tertinggi $0,95 \mathrm{~cm} /$ hari dan yang terendah adalah $0,29 \mathrm{~cm} / \mathrm{hari}$.

Dari hasil data di atas dapat dijelaskan bahwa tingginya rata-rata laju tanaman pada fase 16HST - 30/34 HST karena pada fase tersebut tanaman kedelai berada pada fase aktif pertumbuhan vegetatif sehingga laju tinggi tanaamannya tinggi. Pada fase 0 - 16 HST rata-rata laju tinggi tanamannya masih lebih rendah dari fase vegetatif karena pada fase ini tanaman masih dalam proses perkecambahan dan pertumbuhan awal sehingga laju tinggi tanamannya masih terkendala. Sedangkan pada fase 30/34 HST - 90 HST laju tinggi tanamannya paling rendah karena pada fase ini tanaman kedelai sudah masuk fase berbunga, pembentukan polong sampai pada pengisian polong dimana laju tinggi tanaman mulai melambat karena tanaman aktif pada proses generatif.Bahkan dapat dikatakan pada fase pematangan polong sampai panen pertumbuhan vegetatifnya (tinggi tanaman) adalah stagnan.

Menurut Lakitan (2004) kecepatan tumbuh tanaman dipengaruhi oleh adanya sinkronisasi antara ketersediaan unsur hara dengan kebutuhan tanaman. Hal ini sejalan dengan Rosmarkam dan Yuwono (2002) nitrogen merupakan unsur hara utama bagi pertumbuhan tanaman terutama pada fase vegetatif karena nitrogen merupakan penyusun dari semua protein,selain itu merupakanpenyusun protoplasma secara keseluruhan. Pernyataan tersebut sejalan dengan hasil penelitian yang dilakukan, dimana pada pemupukan dasar menggunkan pupuk urea yang mana mengandung unsur nitrogen (N) di dalamnya. Selain itu, juga dilakukan pemupukan susulan dengan menggunakan pupuk majemuk NPK compaction 15-1515+TE merek DGW produksi dari PT. Hextar Fertilizer Indonesia dengan dosis 140,06 kg/hauntuk menambah ketersediaan unsur $\mathrm{N}$ dalam tanah yang dibutuhkan oleh tanaman dalam pertumbuhannya. Hal ini sejalan dengan Sarief (1989), pada umumnya nitrogen sangat diperlukan untuk pembentukan atau pertumbuhan bagian-bagian vegetatif tanaman seperti daun, batang, dan akar.Menurut Jumin (2005) pertumbuhan vegetatif tanaman akan baik apabila unsur hara yang diberikan cukup bagi tanaman. Hasil penelitian yang dikemukakan oleh Husin (1986) dan Munir (1990) yang menghasilkan bahwa pemberian pupuk kandang dan pupuk $\mathrm{P}$ dapat meningkatkan pertumbuhan dan hasil Kedelai pada lahan PMK. 


\section{Hasil Panen}

Panen dilakukan apabila 95\% polong pada batang utama telah berwarna kuning kecoklatan dengan ciri-ciri tanaman mengering, berwarna kuning, batang mulai mengeras, polong keras dan berubah warna menjadi kecoklatan dengan cara memotong pangkal tanaman menggunakan sabit. Sebenarnya panen dapat dilakukan pada umur tanaman 90 HST, karena kondisi tertentu pemanenan baru dilakukan pada umur 96 HST, yaitu waktu sore hari dari pukul 15.00 sampai selesai. Hasil dari panenan ini segera dijemur selama beberapa hari setelah dirasa cukup (kalau digebuk bijinya sudah mudah terkelupas dari polongnya. Adapun hasil data panen dapat dilihat pada tabel di bawah ini.

Table 2. Hasil Pengamatan Jumlah Polong, Jumlah Biji dan Berat Biji Hasil Panen.

\begin{tabular}{|c|r|r|r|}
\hline \multirow{2}{*}{ NO. PLOT } & \multicolumn{3}{|c|}{ HASIL PANEN } \\
\cline { 2 - 4 } & POLONG (Bh) & BIJI (Bh) & BERAT (Gr) \\
\hline 1 & 52 & 106 & 20 \\
2 & 117 & 250 & 41 \\
3 & 67 & 124 & 24 \\
4 & 142 & 306 & 56 \\
5 & 171 & 375 & 57 \\
6 & 92 & 210 & 41 \\
7 & 164 & 330 & 55 \\
8 & 51 & 94 & 17 \\
9 & 102 & 171 & 40 \\
10 & 110 & 239 & 44 \\
11 & 152 & 334 & 61 \\
12 & 63 & 133 & 25 \\
13 & 131 & 281 & 44 \\
14 & 128 & 278 & 44 \\
15 & 122 & 273 & 44 \\
16 & 70 & 156 & 26 \\
17 & 93 & 203 & 36 \\
18 & 134 & 278 & 52 \\
19 & 141 & 298 & 52 \\
20 & 53 & 104 & 22 \\
21 & 121 & 288 & 45 \\
22 & 140 & 304 & 54 \\
23 & 139 & 294 & 52 \\
.- &.-- &
\end{tabular}

\begin{tabular}{|c|c|c|c|}
\hline 24 & 136 & 315 & 45 \\
\hline 25 & 101 & 234 & 39 \\
\hline 26 & 114 & 235 & 36 \\
\hline 27 & 86 & 197 & 36 \\
\hline 28 & 163 & 312 & 55 \\
\hline 29 & 92 & 198 & 41 \\
\hline 30 & 102 & 237 & 38 \\
\hline 31 & 114 & 249 & 36 \\
\hline 32 & 102 & 197 & 36 \\
\hline 33 & 135 & 301 & 53 \\
\hline 34 & 49 & 107 & 20 \\
\hline 35 & 125 & 273 & 52 \\
\hline 36 & 116 & 234 & 36 \\
\hline 37 & 115 & 201 & 33 \\
\hline 38 & 149 & 340 & 62 \\
\hline 39 & 117 & 251 & 44 \\
\hline 40 & 141 & 329 & 55 \\
\hline 41 & 92 & 188 & 34 \\
\hline 42 & 138 & 314 & 41 \\
\hline 43 & 198 & 405 & 62 \\
\hline 44 & 112 & 234 & 40 \\
\hline 45 & 137 & 326 & 44 \\
\hline 46 & 116 & 247 & 48 \\
\hline 47 & 154 & 307 & 53 \\
\hline 48 & 157 & 371 & 60 \\
\hline JUMLAH & 5.616 & 12.031 & 2.051 \\
\hline RATA-RATA & 117 & 250,65 & 42,73 \\
\hline
\end{tabular}

Sumber : Hasil Penelitian.

Dari tabel di atas dapat dilihat kalau jumlah polong per lubang tanaman adalah rata-rata 117 buah per lubang tanaman dimana tiap lubang tanaman ada 2 dan 1 tanaman.Dengan asumsi tiap lubang 2 tanaman, maka rata-rata jumlah polong per tanaman adalah $117: 2=58,5$ polong pertanaman. Pada tabel juga terlihat jumlah biji per lubang tanam adalah ratarata 250,65 biji, apabila asumsi per lubang tanam 2 tanaman maka rata-rata jumlah biji per tanaman adalah 250,65: $2=$ 125,33 biji per tanaman. Sedangkan untuk berat hasil panen adalah rata-rata $42.73 \mathrm{gr}$ per lubang tanam, dan apabila asumsi per lubang tanam 2 tanaman maka rata-rata berat biji panen per tanaman adalah 42,73: $2=21,37$ gram. 
Dari data di atas, dapat dihitung jumlah hasil panen per ha yaitu, karena sampel 48 dari 320 sampel maka $(48: 320)=0,15$ dari keselurahan sampel dengan luas lahan $35,7 \mathrm{~m} 2$. Luas lahan sampel adalah 0,15 $\mathrm{X} 35,7=5,36 \mathrm{~m} 2$, jadi untuk menghitung hasil panen per ha adalah $(10.000 / 5,36) \mathrm{x}$ $2.051=3.836 .492,54 \mathrm{gr} / \mathrm{ha}=3.836,49$ $\mathrm{kg} / \mathrm{ha}=38,36 \mathrm{kw} / \mathrm{ha}=3,83$ ton/ha.Juga bisa dihitung berat/bobot per 100 butir kedelai adalah berat seluruh biji/jumlah seluruh biji $\times 100=0,17 \times 100=17$ gr/100 biji.

Hasil panen 3,83 ton/ha melebihi daya hasil yang ada pada deskripsi varietas anjasmoro yaitu hanya 2,03-2,25 t/ha atau ada peningkatan hasil $70,22 \%$ dari deskripsi. Begitu juga dengan bobot 100 biji, dimana dalam deskripsi tercatat untuk varietas anjasmoro 14,8-15,3 gr padahal hasil penelitian $17 \mathrm{gr} / 100$ biji sehingga terjadi peningkatan bobot 100 biji sebesar $11,11 \%$.

Hal tersebut di atas dapat terjadi, bisa saja dimungkinkan karena adanya bias dalam menghitung hasil panen per ha, tetapi juga bisa karena tanaman dapat tumbuh optimal yang disebabkan tersedianya unsur hara yang dibutuhkan tanaman melalui penggunaan pupuk majemuk NPK compaction 15-15-15+TE merek DGW produksi dari PT. Hextar Fertilizer Indonesia. Hasil pengkajian yang dilakukan di desa Gambirono, kecamatan Bangsalsari, Jember menunjukkan bahwa penggunaan pupuk PHONSKA (pupuk majemuk) sebanyak $75 \mathrm{~kg} / \mathrm{ha}$ memberi hasil panen kedelai sebanyak 2,33 t/ha atau hasil meningkat $24 \%$ dibanding tanpa PHONSKA.Hasil panen yang tinggi seperti di atas dapat tercapai karena unsur hara bagi tanaman dapat tersedia secara optimal terutama unsur N,P,K (melalui pemupukan), serta faktor penghambat lainnya seperti kualitas benih/bibit, iklim, irigasi, gangguan gulma dan hapen dapat dikendalikan sehingga tanaman dapat tumbuh secara optimal. Perlu juga diperhatikan, bahwa penggunaan pupuk majemuk NPK hanya direkomendasikan pada pemupukan susulan mengingat ketersediaan pupuk tunggal N,P,K di pasaran ketersediannya cukup langkah dan walaupun ada terkadang harga jualnya mahal jauh diatas harga subsidi. Namun tidak menutup kemungkinan penggunaan pupuk majemuk NPK bisa digunakan sebagai pupuk dasar apabila pupuk tunggal NPK tidak tersedia agar unsur hara esensial khususnya NPK tetap tersedia bagi tanaman. 
Berat bobot 100 biji tergolong tinggi dimungkinkan karena ketersediaan phosfat (P) yang tersedia cukup bagi tanaman, karena pada fase generatif phospat merupakan senyawa penyusun jaringan tanaman yang berfungsi menyimpan dan mentransfer info gen serta sebagai penyusun membran sel. Phospat juga diperlukan untuk pembentukan primordia bunga dan organ tanaman untuk reproduksi. Peran phospat yang lain adalah dapat mempercepat masa pembungaan dan mempercepat masaknya buah dan biji pada tanaman, selain itu juga berfungsi sebagai penyusun lemak dan protein. Unsur hara phospor berperan dalam proses metabolisme tanaman, sehingga unsur ini sangat penting dalam fotosintesis. Bila unsur $\mathrm{P}$ tanaman terpenuhi maka fotosintesis akan berjalan dengan lancar dan karbondidrat dalam biji kedelai yang dihasilkan dari prosen fotosintesis ini akan bernas atau berisi.

Hal ini sejalan dengan Rosmarkam dan Yuwono (2002) menyatakan, metabolisme karbohidrat pada daun dan pemindahan sukrosa juga dipengaruhi oleh phospat.Pada proses pertama, penyusunan sukrosa dan heksosa memerlukan phospat energi tinggi (ATP dan ADP). Oleh karena itu, phospat diperlukan dalam sel dan waktu penyusunan karbohidrat sangat berkaitan dan bergabung dengan pati, terutama pada tanaman biji-bijian dan serelia.

Bukan unsur $\mathrm{P}$ (phosfat) saja yang berpengaruh terhadap kebernasan bobot biji, selain itu apabila tanaman tercukupi akan kebutuhan unsur hara nitrogennya maka menyebabkan daun bertambah lebar, sehingga klorofil yang terbentuk juga optimal untuk proses fotosintesis tanaman. Glukosa yang dihasilkan dalam proses fotosintesis ini akan berubah menjadi pati atau karbohidrat didalam polong. Hal ini akan membuat polong lebih berisi. Hal ini sejalan dengan Wati (2014), bahwa unsur nitrogen adalah bagian dari zat hijau daun yang berperan dalam penyerapan sinar matahari, bagian dari protein sehingga dapat menambahan kandungan protein dan mendorong pertumbuhan daun serta dapat meningkatkan bobot dari biji kedelai tersebut.

Oleh karena itu peningkatan produksi hanya dapat dicapai jika diberi tambahan hara tanaman untuk pertumbuhan yang optimal, baik itupemupukan maupun melalui proses lainnya. Di samping itu, pupuk akan berguna bagi tanaman karena dapat mempercepat pertumbuhan tanaman dan memperkuat akarnya. Bahkan dengan 
pemupukan dapat juga menambah daya tahan tanaman tahan terhadap hama dan penyakit tertentu. Pupuk merupakan makanan bagi tanaman,oleh karena itu agar tanaman dapat tumbuh dengan baik harus diberikan apa yang dibutuhkan oleh tanamantersebut. Dwidjoseputro (1986) menyatakan bahwa suatu tanaman akan tumbuh baik dan subur apabila semua unsur hara yang dibutuhkan berada dalam jumlah yang cukup dan tersedia bagi tanaman. Lingga (1994) juga mengemukakan jika unsur hara yang dibutuhkan tanaman tersedia dalam jumlah yang cukup, maka hasil me-tabolisme seperti sintesis biomolekul akan meningkat. Hal ini menyebabkan pembelahan sel, pemanjangan dan pendewasaan jaringan menjadi lebih sempurna dan cepat, sehingga pertambahan volume dan bobot kian cepat yang pada akhirnya pertumbuhan tanaman menjadi lebih baik.

\section{KESIMPULAN DAN SARAN}

\section{Kesimpulan}

Penanaman kedelai varietas anjasmoro di lahan Balai Latihan Pertanian Sentani dengan penggunaan pupuk majemuk NPK compaction 15-15-15+TE merek DGW produksi dari PT. Hextar Fertilizer
Indonesia dengan dosis 140,06 kg/ha dapat menghasilkan rata-rata tinggi tanaman $86,85 \mathrm{~cm}$ (lebih tinggi dari catatan deskripsi) dan hasil panen dengan produksi 3,83 ton/ha (lebih tinggi 70,22\% dari deskripsi) serta bobot 100 biji adalah 17 gr/100 biji (11,11\% lebih tinggi dari deskripsi). Kenyataan tersebut dapat terjadi karena kebutuhan unsur hara bagi tanaman khususnya N,P,K tersedia optimal serta faktor pembatas lainnya dapat terkendali sehingga tanaman dapat tumbuh dan berproudksi secara maksimal

\section{Saran}

Penggunaan pupuk majemuk NPK dapat direkomendasikan pemakaiannya sebagai pupuk susulan untuk meningkatkan pertumbuhan dan prouduksi kedelai. Walaupun demikian, pupuk majemuk NPK juga bisa digunakan sebagai pupuk dasar bila ketersediaan pupuk tunggal N,P, dan $\mathrm{K}$ tidak tersedia atau lebih mahal dengan memperhatikan kecukupan atau dosis pemakaiannya.

\section{DAFTAR PUSTAKA}

Badan Pusat Statistik. 2012. Luas Panen, Produktivitas dan Produksi Kedelai Nasional. http//www.bps.go.id.

Dwidjoseputro, D. 1986. Pengantar Fisiologi Tumbuhan. Gramedia. Jakarta 
Ernawanto Q D, Noeriwan B S, Sugiono. 2011. Pengaruh pemberian zeolit terhadap pertumbuhan dan hasil tanaman kedelai. Prosiding seminar Hasil Penelitian Tanaman Aneka Kacang dan Umbi. Jawa Timur.

Husin, E.F. 1986. Pengaruh Pupuk Kandang dan Posfor Terhadap Ketersediaan P, Pembentukan Nobula dan Hasil Kedelai Pada Tanah Podsolik. Thesis Fakultas Pasca Sarjana UNPAD Bandung.

Jumin, H B. 2005. Dasar-dasar Agronomi. Jakarta : Raja Grafindo Persada.

Lakitan, B. 2004. Dasar-dasar Fisiologi Tumbuhan. Raja Grafindo Persada. Jakarta.

Lingga, P. dan Marsono. 2005. Petunjuk penggunaan pupuk. Penebar Swadaya, Jakarta. $250 \mathrm{hlm}$.
Munir, R. 1990. Pengaruh Pemberian Pupuk Kandang dan Pupuk P Pada Podsolik Merah Kuning Terhadap Pertumbuhan dan Hasil Kedelai. Thesis Fakultas Pasca Sarjana KPK IPB-Unad. Padang.

Rosmarkam, A. dan Yuwono, N. 2002. Ilmu Kesuburan Tanah. Kanikus. Yogyakarta.185 Hal.

Sarief, S. 1989. Kesuburan dan Pemupukan tanah pertanian. Pustaka Buana. Bandung.248 Hal.

Wati, Y.T. 2014. P engaruh Aplikasi Biourin Pada Pertumbuhan Dan Hasil Tanaman Bawang Merah (Allium ascalonicum L.). Skripsi. Jurusan Budidaya Pertanian, Fakultas Pertanian, Universitas Brawijaya. Malang 